\title{
Disentangling life: Darwin, selectionism, and the postgenomic return of the environment (2017)
}

Maurizio Meloni

\begin{abstract}
In this paper, I analyze the disruptive impact of Darwinian selectionism for the century-long tradition in which the environment had a direct causative role in shaping an organism's traits. In the case of humans, the surrounding environment often determined not only the physical, but also the mental and moral features of individuals and whole populations. With its apparatus of indirect effects, random variations, and a much less harmonious view of nature and adaptation, Darwinian selectionism severed the deep imbrication of organism and milieu posited by these traditional environmentalist models. This move had radical implications well beyond strictly biological debates. In my essay, I discuss the problematization of the moral idiom of environmentalism by William James and August Weismann who adopted a selectionist view of the development of mental faculties. These debates show the complex moral discourse associated with the environmentalist-selectionist dilemma. They also well illustrate how the moral reverberations of selectionism went well beyond the stereotyped associations with biological fatalism or passivity of the organism. Rereading them today may be helpful as a genealogical guide to the complex ethical quandaries unfolding in the current postgenomic scenario in which a revival of new environmentalist themes is taking place.
\end{abstract}

Keywords: Environment- Darwin - James- Weismann- Epigenetics- Postgenomics

\section{The social significance of selectionism: revisiting the case in the postgenomic age}

We possess a well-defined picture of the way in which Darwin's natural selection absorbed and projected some of the wider social values of his time onto nature, as well as many of the intellectual sources (Malthus in primis) behind this transfer of values. However, the reverse relationship, the impact of Darwinian selectionism on the wider social and intellectual landscape remains a much more problematic area of investigation. Here, truly bogeymen terms such as Social Darwinism or eugenics have historically hampered a balanced evaluation, regardless of the tenuous historical validity of the former (Bannister, 1988), and the less than direct relationship of Darwin with the latter (Paul, 2009). Selectionism remains mostly a bad word outside of biological circles, where the term is still associated with crude ideas of merciless competition, harsh militarism, extermination of 'inferior races', or a sanction for the 
old argument that "might makes right" (see Browne, 2002, p. 107). The debate on the impact and popularization of Darwin's idea of natural selection beyond the strict biological realm goes well beyond the limited space of this (or any) article. Here I want to consider a specific aspect of the social and moral implications of the rise of selectionism in the second half of the nineteenth century. Its impact on the "ancient doctrine" (Wallace, cited in James, 1880, p. 452) according to which external circumstances ${ }^{1}$ shape directly an organism's traits, including the mental and moral features in humans. In this environmentalist trend, nature literally impressed itself upon the organism, making its imbrication with the immediate surroundings difficult, if not impossible, to disentangle. This mode of thought, which was based on a logic of imprint rather than se- lection, was extremely influential from the time of Greek medicine and historiography at least until to the geographical and political speculations of authors like Bodin and Montesquieu at the begin- ning of Western modernity. The nineteenth century, as I will argue, represented both a modification and a radicalization of this approach that was brought to a climax by Lamarckism. It is against this century long trend that I suggest we should read the corrosive function of Darwin's key notion: natural selection. With its appa- ratus of indirect effects, random variations, a much less harmonious view of nature, and a more complex understanding of adaptation (Bannister, 1988; Ospovat, 1995; Worster, 1985), selectionism severed the deep imbrication of organism and milieu posited by traditional environmentalist models. In so doing, it precipitated a crisis in the totalizing view of the environment shared by pre-Darwinian authors. The environment lost much of its creative force becoming, as critics notice today,

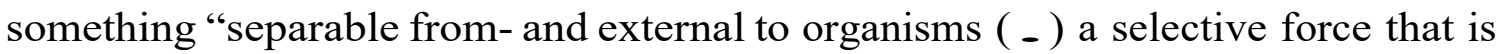
passive rather than generative" (Moczek, 2015, p. 1). In evolutionary theory, this disentanglement (or "alienation") of the organism from its immediate circumstances is often perceived as an impoverished view, though necessary for the time (Lewontin, 1983, p. 106). But what about its wider implications outside the

\footnotetext{
${ }^{1}$ In the text, I will use rather freely and interchangeably terms such as circumstances, milieu, medium, environment, conditions of life, and surroundings. Although I am aware of the complex historical and philosophical issues related to the various usages of these different terms (Koller, 1918; Spitzer, 1942; Canguilhem, 2001; Pearce, 2010), in this essay I have abstracted away from their different nuances guided by my specific research questions.
} 
biological realm? This is what my article aims to excavate. By allowing for an unprecedented distance between humans and their milieu, I argue that selectionism fav-oured a way of thinking about human agency and the origin of mental faculties that could escape the rigid scaffolding of environmental determinism. This picture is quite different from the usual associa- tions of selectionism with a passive view of the organism, or with biological fatalism.

Before going into details, however, it seems important to clarify that my interest in revisiting this key moment in intellectual history is not (merely) genealogical. Under what is known as post- genomics, over the last few years we have witnessed a (re)emergence of views based on a deep entanglement between organisms and their surroundings. Claims have emerged of an environmental- turn in the life-sciences, and a (re)discovery of the constitutive role of the environment in directly shaping biological mechanisms, as the case of environmental epigenetics powerfully illustrates (Landecker \& Panofsky, 2013; Shostak \& Moinester, 2015; Landecker, 2016a; b; Martin \& Warin, in press). Views that were marginalized if not repressed, first by selectionism and later by genetics, have powerfully re-emerged: as seen for example in notions of the body, development, and heredity that are open and plastic, profoundly embedded in their surroundings, and directly shaped by social pressures (Guthman \& Mansfield, 2013).

The present awareness of some form of epistemic shift in the relationship between the organism and its surrounds is well exem- plified by a recent article by Hannah Landecker in this journal. Landecker correctly contrasts the selectionist logic of genomics with the "logic of imprints" that, in recent epigenetics writings, gives new centrality to the "experiential and physical milieu" (2016a). However, as Landecker herself makes clear, this shift is far from being merely a technical change in the mechanisms of evolution. Epigenetics, and a returning view of the power of the environment, has a broader significance for knowledge-production, i.e. in the relationship between biological and socio-historical knowledge. The argument here, as historian Ken Alder has noticed in speaking of episcience (2013), is that epigenetics replaces genetics in the same way that a style of thought favoring the "imbrication of science with its "surround" supplants a neat modernistic separation between content and context, knowledge and its medium 
(Alder, 2013, p. 96). While I agree with this analysis, my point is that in the present postgenomic return to "entrenched ways of conceiving causation and agency" (Alder, 2013, p. 97) there is more at stake than mere knowledge-production. As my essay aims to show, complex moral themes were woven into the fabric of the environmentalist-selectionist controversy. A whole moral constellation was associated with the notion of a deep entanglement between organism and milieu. The environmentalist doctrine that circumstances exerted a direct power very often led to judgements and moralistic connections being made between peo- ple and places (Livingstone, 1992). The empire of the environment was not always a benign one. This is why, without indulging in any naïve use of history, the current postgenomic fascination with non- selectionist modes of understanding the organism-environment relationship may have wider moral and political repercussions that past debates can help excavate and situate.

The essay now proceeds in four steps. Firstly, I will trace con- ceptions of the power of the environment in shaping directly hu- man traits in pre-Darwinian authors. Following William James, I will gather these different lines of thought under the label of "the environment as a producer". Secondly, I will summarize how Dar- win escaped such a seemingly attractive way of thinking with his idea of natural selection and how this move was profoundly destabilizing for the ancient environmentalist tradition. Thirdly, I will look at an aspect of the moral topography of this debate by focusing on two key post-Darwinian authors, William James and August Weismann. They both addressed mental evolution following a selectionist method, with important implications for notions of human agency, social change and even racial differences. Finally, I will conclude by briefly coming back to our postgenomic present and highlighting some of the quandaries associated with its view of a radical organism-environment entanglement.

2. The environment as a producer

In his Notes on the Philosophy of Evolution, William James introduced a crucial heuristic distinction between two ways of understanding the environment in evolution: the environment as a "producer" of variations and as a "regulator" (or 
“preserver"). The first is the notion (largely shared by pre-Darwinian authors) that the organism is "plastic to environment" and that there is every- where "adaptation" and a perfect correspondence between organism and its surroundings (1988, p. 137). The second is the genuine view originating from the Origin of Species. While it would be obviously unfair to summarize in just a couple of aphorismatic lines centuries of conflicting views, there is a sense in which James' comments are a helpful tool for bringing to light a possible common trait among various streams of pre-Darwinian thought. My aim in this section is not to argue for a monolithic image of the pre- Darwinian environment from Hippocrates until Spencer. There are excellent historiographic reconstructions of the long-term history of environmentalism with its many nuances and qualifications (Glacken, 1967; Koller, 1918; Thomas, 1925) as well as detailed analysis of the making of the term milieu or environment (Spitzer, 1942; Canguilhem, 2001, pp. 6, 31; Pearce, 2010).

Nonetheless, to go back once again to this story is helpful here for various reasons. Firstly, against frequent claims of a domination of dualism in Western thought (see critical overviews in Meyer, 1999; Newton, 2007), a soberer reflection in fact invites us to give equal importance to materialistic-naturalistic frameworks that posited a pro- found entanglement between an organism and its life's conditions. Secondly, contemporary claims about an "environmental-turn" in the life-sciences (see refs above, p. 3) need to be situated in a much longer perspective where the towering power of the environment always mattered, as did the notion of the organism as plastically adapted to and molded by its direct surroundings. Trapped in the mystique of fixity created by the century of the gene, the ubiquitous presence of this long-term environmentalist tradition is often forgotten in social analysis of postgenomics. Thirdly, pitting Darwin's contribution against this specific naturalistic- environmentalist tradition is a productive way to enlarge the effectiveness of the Darwinian revolution beyond more established dichotomies (evolutionism/creationism; teleology/non-teleology; essentialism/population thinking) which have dominated debates within the history of biology. What my reading suggests is that Darwin's genius was to offer a radical critique of the powerful environmentalist tradition without dismissing the role of the environment 
(as internalists would) but rather, radically repositioning $i^{2}{ }^{2}$. In this way, Darwin opened intellectual possibilities that were unknown before the Origin.

\subsection{The empire of the environment: from Hippocrates to early modernity}

Historians of various disciplines, geography, medicine, and anthropology in particular, are well-aware of the long-term influence of an environmentalist framework that interpreted the living organism, and in the case of humans their behaviour and mentality too, as directly shaped by and dependent on the physical conditions of existence (Glacken, 1967; Koller, 1918; Thomas, 1925). Far from being residual, environmentalism remained for centuries "a way of conceiving and understanding the world" (Rosenberg, 2012). It is commonplace to refer to the Hippocratic "Airs, Waters, Places" (IV BCE) as the beginning of a tradition where a direct connection is established between the physical environment (air, water supply, climate, soil, winds, and positions of the stars and planets) and not only bodies but also more broadly customs, intelligence, and the character of different populations. In Hippocrates, the "mental flabbiness and cowardice" of the Asiatics, for instance, is explained in relation to the small variations of their climate; the warlike temperament of the Europeans originates instead from a more variable weather (Koller, 1918; Lloyd 1978). In this ancient litera- ture, the body is conceived as profoundly embedded in its places (Rosenberg, 2012), "characterized by a constant exchange between inside and outside, by fluxes and flows, and by its close dependence on the surrounding environment" (Nash, 2006, p. 32). Humoralist theories in medicine were the best representative of this profound imbrication between human bodies and their places, food, or habits. But well beyond medicine, significant environmentalist themes can be found in historians like Herodotus and later Polybius and Pliny, as well as in philosophers like Aristotle (Thomas, 1925). At the very origin of Western thought a worldview based on the direct effects of the environment on the human body and soul was therefore solidly

\footnotetext{
${ }^{2}$ A way to look at this is to claim that Darwin was an externalist but of a special kind given that, as also Winther acknowledges, "when dealing with the nature of variation ( - ) he prioritized the nature of the organism" (2000, p. 440). In the selectionist tradition, external changes remained the "triggering cause of variation", something that also applies to Weismann (Winther, 2001): this is not different from what I mean by repositioning the role of the environment, although I think it is fair to insist more on the disruptive value of this gesture.
} 
established.

A revival of this explanatory style can be found in the Renaissance, especially in a political context. Here, the far-reaching con- sequences of geography on the making of national characters were emphasized. In The Six Books of the Commonwealth (1576/1962), Jean Bodin explores the manifold effects of climate on the "diverse conditions of men". Bodin sketches a complex analysis of individual temperament and political character along a series of geographical oppositions: North-South, EastWest, mountains-plains, exposure to soft winds or violent tempests, hills-lower parts of town (with hilly cities, the case of Rome being one, marked by profound political instability). Although Bodin was careful to make room for human agency and divine will (Febvre, 1924, p. 4) the way he links history and places, physical conditions and human temperament, is resonant with older Hippocratic and astrological traditions, often mediated via Medieval thought (Tooley, 1953). Two aspects emerge strongly from Bodin's environmental determinism: the hierarchical order of causality from the physical elementa (earth, fire, air or water) to the human mind (anima) via the causal chains of human body, blood, and soul (Tooley, 1953, p. 68); and secondly the fundamental plasticity of human populations. Given the causal primacy of places for Bodin, a geographical migration implies also a change of character: "If men are transplanted from one country to another, although they do not react as quickly as plants which suck their nourishment from the very soil, nevertheless in time they also will change.” (1962, book V).

It is, however, only in the eighteenth century that theories positing a deep connection between humans and their environment reached a climax, with physical causes no longer playing an ancillary role to other religious or astrological factors (Glacken, 1967, p. 551, 622 in particular). Montesquieu's Spirit of the Laws (1748, particularly books XV-XIX) is an obvious reference. Here, following rather strictly ancient authors (Isaac, 2006, p. 45), "the empire of the climate" is vividly celebrated as a powerful force capable of producing temperamental, moral, cultural, political and institutional variations. The inextricable embedment of national institutions to local physical conditions is confirmed by the famous antagonism in Montesquieu between hot climate and despotism on one side, and cold climates and liberty on the other. Given these 
physical constraints to political action, the capable legislator must rule by skillfully navigating the generative dynamism of the climate. "Institutions are excellent in proportion as they are adapted to a particular environment" is a theme almost literally repeated by William Graham Sumner more than one century later (Thomas, 1925, p. 14). Montesquieu also anticipates another trope of later views: that once the environment has made a population, it cannot unmake them (Huntington, cited in Campbell \& Livingstone, 1983, p. 277), for example, in the case of Tartars who, for Montesquieu "carried into their deserts that servile spirit which they had acquired in the climate of slavery" (1752/1914, p. 353).

Montesquieu's environmentalism was not unchallenged, obviously, and many authors expressed skepticism to his sweeping claims (Voltaire), or wanted at least to make subtler and more complex his generalizations (Herder). The way in which Buffon situates himself vis-à-vis this environmentalist debate is particularly interesting. Buffon is a much more complex figure than Montesquieu in his analysis of the relationship between man and the environment. For Buffon, humans can create humanized spaces where the direct influence of the climate is reverted, unlike other animals (Febvre, 1924, p. 8; Glacken, 1967, p. 503). However, an appreciation of this active role of humankind, should not obscure three important points in Buffon's contribution to the long-term environmentalist narrative. These factors have enabled historians to claim that Buffon's rejection of geographic determinism "was at best partial” (Sloan, 1973, p. 306). Firstly, Buffon's theory of race formation makes direct environmental influences the key to explaining racial variations, allowing him to save his professed monogenism (Sloan, 1973). Of the three causes (climate, food and customs) that directly produce racial variations (“degeneration"), climate is the most important, but food (acting molecularly on the "internal mold") is the channel through which the power of places enters and shapes the human body. Secondly Buffon's theory of generation relies profoundly on an environmental model in which, again mostly via nutrition, external influences are passed directly on to the semen where they form the basis for the bodily organisation of the new generation (Zirkle, 1946).

Thirdly, and more importantly in a long-term perspective, Buffon crucially links for the first-time two different historical strands (Canguilhem, 2001, p. 9): i) the older 
anthropogeographic tradition of Bodin and Montesquieu (including the Hippocratic corpus); ii) and Newton's cosmology, from which the notion of milieu origi- nates, as a French translation for fluid (Canguilhem, 2001, p. 8). It is upon this complex legacy that much of nineteenth century environmentalism, particularly via Lamarck (Buffon's student), will capitalize.

\subsection{Nineteenth century imbrications of organism and milieu}

The nineteenth century produced both a significant shift and a radicalization of this environmentalist framework. On one side, the old natural theology with its broad physical and climatic terminology started to decline, giving way to a biological and evolutionary lexicon. On the other side, some of the older physicotheological wisdom survived in views of biological adaptation as the result of a harmonious and pre-established correspondence between milieu and organism (Glacken, 1967; Ospovat, 1995). Importantly, the nineteenth century is the moment when the term milieu loses its technical connotation to gain widespread and cross- disciplinary popularity. The impact of the term on the social sciences is profound. The sociology of Comte largely depended on and expanded the notion of milieu (Braunstein, 1997; Koller, 1918; Petit, 1997). Later in the century, French and Belgian sociologists Jacques Bertillon (1872) and Guillaume De Greef (1886-89) introduced, separately, the notion of "mesologie" as an autonomous subfield of sociology aimed at studying the influence of different milieus on social groups. In wider society, novelists like Balzac and later Zola, public intellectuals and historians like Renan, Taine or in England Buckle, made the milieu into a veritable heuristic key to explain the laws and directions of historical developments. Nietzsche, always an excellent intellectual seismographer, noticed sarcastically in 1885 how the "milieu-theory" was used recklessly in any possible field but with little explanatory gain (cited in Spitzer, p. 184). The complex terminological fate of the term as it travelled from various disciplinary contexts and linguistic traditions has been carefully documented (Spitzer, 1942; Canguilhem, 2001, pp. 6-31; Pearce, 2010). In the context of my analysis, two things remain important to highlight, however. Firstly, the reification of the concept in the nineteenth century. What originally started as a relational term, to 
define in Newtonian physics a field of relationships between two bodies (Canguilhem, 2001, p. 8), became gradually a self-standing entity endowed with causal explanatory power. Secondly, the impersonal view of external natural forces typical of eighteenth century mechanism, takes on a different connotation in nineteenth century biology. The environment, the immediate or external circumstances, the conditions of existence became a true milieu createur, something elevated to a role that is the "materialistic equivalent of divinity" (Jordanova, 1989; Tresch, 2012). Here the contribution and allure of Lamarck is difficult to overestimate. Lamarckism gave an enormous causal power to what he called circonstances influentes raising the notion of direct external effects to an unprecedented extent. This had a huge resonance for social groups often leaning to political radicalism that, as in the British context, aimed to challenge the medical and theological establishment with a strong naturalistic theory (Desmond, 1990). Lamarck's dependence on a fully materialistic and physicalistic view of life, with roots in Greek philosophy and chemistry, and "faith in anything but body" (cited in Burkhardt, 1977, p. 189), has been largely and in my view correctly emphasized (Corsi, 1988, p. 119; Gillispie, 1959; Gould, 2002). No matter Lamarck's own emphasis on le pouvoir de la vie, his framework was strictly mechanistic, stressing the power of "the motion of fluids in the animal body which would carve channels and cavities in soft tissues, and gradually lead to the evolution of increasing organisational complexity" (Koonin \& Wolf, 2009, p. 42; see also; Gould, 2002). The mechanical linkages that connected the interior of the organism to its external environment were described by Lamarck following a sort of hydraulic model, made of "pipes, tubes, canals, and other equivalent spaces" (Gissis, 2011, p. 24). If one adds to this materialistic undertone, the absolute predictability and lack of randomness in the organism's responses to external changes (Lennox, 2015), one can easily see why Lamarckism made very difficult the possibility of a disentanglement between the organism and its milieu. True, in higher organisms, the environment's demands were mediated by subjective needs. But in Lamarck it is always the environment "that changes first" (Gould, 2002, p. 177). While it is fair to recognize that in Lamarck there were tensions between mechanism and vitalism, forces and wants, I struggle to see how his naturalism could leave much room for individual 
spontaneity. The anthropological implications of this position are noticeable. For Lamarck, "people have no real creativity or imagination" of their own; "all ideas come from nature, with the consequence that transcendence of the material world is impossible" (Jordanova, 1984, p. 87).

A similar problematic is inherent in the worldview of Herbert Spencer. Spencer's case illustrates well that if one takes seriously the "intimate relation between the being and its medium" (Ribot, 1874, p. 158), then it becomes extremely difficult to set apart organic from non-organic forces (Bidney, 1953, p. 35). Firstly, if useinheritance is the key mechanism to explain the heredity of the highest faculties, as Spencer wanted following Lamarck, the social dimension is always on the verge of becoming biological: a previous generation's behavioral acquisitions will become organic in a successive one. Secondly, in parallel to this, Spencer made of Von Baer's embryological law of organic development the cornerstone of his combined view of organic and social progress from the "most general" to the "most specialized" (1857) with no space for a possible disjunction between biological and moral progress (Weinstein, 1998; Gissis, 2011). Both arguments, in passing, contributed to an important confusion between '“race' and 'nation' ( - ) natural history and national history" (Campbell \& Livingstone, 1983, p. 271) with important implications, as we shall see soon, for arguments about racial differences in human talents.

It is paradoxical that it was exactly Herbert Spencer to use in his Principles of Sociology the term super-organic, and was for this reason cited by Kroeber as a precursor of the anthropological notion of culture (1952, p. 3). However, it suffices to read carefully what Spencer means by this term to agree with authors like Bidney (1953) and later Ingold (1986) that Spencer's super-organic and Kroeber's superorganic (1917) are in fact antithetical notions. Spencer, who uses the term always as an adjective (for evolution, growth, products etc.), means by super-organic literally a super- organism (Ingold, 1986, chapter 6), i.e. an extension of the organism beyond the individual level, but not beyond "the organic laws of evolutionary development" (Bidney, 1953, p. 35). Not by chance, the examples offered by Spencer are typically drawn from animal societies (for instance social insects, bees, wasps, birds). It is the "coordinated actions of many individuals" that mostly interests Spencer (1877, par. 2). 
This view has little to do with the superorganic as classically conceived in the Kroeberian tradition (1917), i.e. as something that is above the organic world and its laws and is, accordingly, radically absent among animals. For Spencer, superorganic products result from organic laws, for Kroeber escape them (Ingold, 1986). ${ }^{3}$

Finally, it is worth mentioning here that later in the century, French neo-Lamarckism (differently from its American counter- part) continued and further radicalized a bold materialistic model. Organisms not only bore the marks of their milieu, but in a more than metaphorical sense, they digested and metabolized it, imprinting its features (via nutrition) into heredity (Loison, 2010). Significantly, neo-Lamarckian and Spencerian influences are also to be found in late nineteenth and early twentieth century geography that drew on use-inheritance to make sense of the "interaction between particular physical environments and local cultures" (Campbell \& Livingstone, 1983). It is to this state of affairs and context - a radical embedding of the organism in its surroundings that Darwin selectionism spoke.

\section{The autonomy of the living: selectionism as disentanglement}

\section{(The environment as regulator)}

The way in which Darwin distanced himself from a belief in the direct effects of the environment and conceived an alternative way of thinking about variation and adaptation, i.e. natural selection, is too well known to be retold here (Ospovat, 1995). The sources behind this epistemological break were manifold and include:

a) biogeographical observations showing great organismic varieties in environmentally similar regions, and vice versa, observations showing similarity of organisms in highly heterogenous areas (Darwin, 1845 [1937]; see also for

\footnotetext{
${ }^{3}$ In some passages of his Sociology, Spencer affirms that super-organic products (technology, knowledge, laws, etc.) - "are ever modifying individuals and modi- fying society, while being modified by both" (1877, par. 12). I interpret this as an extension of the organic metaphor to a wider range of operations ("a larger whole", ibid.), not as an acknowledgment of some sort of escape to the power of "incident forces". These super-organic products are still "no less natural than other products of evolution" (ibid.), Spencer argues. I concur with an anonymous reviewer that the above citation represents a shift from the strict correspondence theory of Spencer's Psychology and Biology, but this is still a very different understanding of what counts as superorganic than that found in Kroeber, or, as we shall see soon, in Weismann's notion of Tradition. Finally, it is doubtful that when Spencer says "modifying" he means something extra-organic, given how also in his Sociology (for instance, par. 49) mental powers are always the result of "nervous structure" moulded "by accumulated ancestral experiences", again a point that will become significant when analyzing the different reading offered by Weismann.
} 
context; Amundson, 1994; Hodge, 2009); b) the analogy with breeding practices in domesticated production; c) and the crucial influence of Malthus and political economists in general in highlighting the priority of relations with other living beings over those "with the environment conceived as a collection of physical forces" (Canguilhem, 2001, p. 13). If one rereads the Origin today in the light of the previous analyses on the longevity of an environmentalist tradition, what struck the reader is the absolute confidence of Darwin in dismissing the direct role of external conditions as something of just minor importance. In the following and several other passages, Darwin overtly confesses to have "not much faith" or "to lay very little weight on the direct action of the conditions of life" (1985, p. 105). As he writes: "Naturalists continually refer to external conditions, such as climate, food, \&c. as the only possible cause of variation. In one very limited sense, as we shall hereafter see, this may be true; but it is preposterous to attribute to mere external conditions, the structure, for instance, of the woodpecker, with its feet, tail, beak, and tongue, so admirably adapted to catch insects under the bark of trees." $(1985, \text { p. } 5)^{4}$.

It is beyond the goal of this article a historical treatment of Darwin's personal oscillation in making room for direct environ- mental effects in his evolutionary view. Since Darwin never held that natural selection was the only evolutionary mechanism, some room for direct effects was always left open; in fact, this is space became bigger in his later writings. ${ }^{5}$ However, no matter Darwin's intellectual fluctuations, the discovery of natural selection as a new "paramount" cause for evolution introduced a radically different way to conceive the power of the environment: no longer an immediate creator of organismic change, it was now a selector acting indirectly via the reproductive system. This shift had fundamental consequences for the way the relationship between organism and the environment was conceived. Firstly, variations were now seen as indifferent to

\footnotetext{
${ }^{4}$ Other passages include Darwin's claim that "physical conditions" are insufficient to explain species' distribution (several passages); "how unimportant the direct effects of the conditions of life" are compared to the laws of reproduction, growth and inheritance and how "quite opposite conditions produce similar changes of structure" and only "some slight amount of change may (...) be attributed to the direct action of the conditions of life" (p. 31); finally how "would be a bold man who would account by such agencies [the direct action of the external conditions of life, and habit]" to explain completely organic change. Only "little effect" can be attributed to those agencies (p. 51).

5 Particularly in The Variation of Animals and Plants (1868) where Darwin's argument for pangenesis (27) is an obvious place to look for this environmentalist vein (see Winther, 2000).
} 
environmental changes: they occurred regardless of any adaptive bias (Gould, 2002, p. 145). The pre-established synchronization between milieu and organism was subverted, and the same notion of adaptation was now to be understood according to a more pragmatic, "less-than-perfect" model (Ospovat, 1995). Secondly, organisms' propensity to change was no longer seen as a direct response to "altered external conditions", but as a spontaneous force largely exceeding the direct pressure of external change (Amundson, 1996; Ospovat, 1995). Thirdly, variations were not only indifferent but also "indefinite" (Olby, 2009). This indefiniteness opened a major crack in the edifice of deterministic explanations. Natural selection anticipated a probabilistic view of the relationship between environment and organism based on tendencies rather than fixed effects (Lennox, 2015). More importantly, both selectionism and probabilistic thinking conceived of organisms as spontaneous "sources of variation, not merely as reactors to outside stimuli" (Amundson, 1996, p. 33).

The distance from Lamarckism couldn't be wider: whereas for Lamarck, given a certain environment "all individuals basically acquire the same structures and adaptations" (Kroenfeldner, 2007, p. 499; see; Mayr, 1972), in Darwin "living organisms of the same species exposed to very different conditions often vary not at all; and the offspring of living organisms of the same species subjected to nearly identical external conditions sometimes vary a great deal" (Johnson, 2015, p. 65). The move implies an element of accidentality that disrupted the simplistic unilinear causal process of Lamarckism (ibid., p. 69). It also crucially introduced, against simplistic understanding of selectionism, a stronger role for the autonomy of the organism whose potential for change was no longer a direct resultant of the power of circumstances. Even in tension with Darwin's own romantic understanding of an entangled nature (1985, p. 489), for selectionism organisms (humans included) were now less entangled to their surroundings. The conditions of life acted mostly in an indirect way. The repercussions of this break for the environmentalist imagination didn't wait to show.

\section{A selectionist critique of the moral idiom of environmentalism: James and Weismann}


An evaluation of the long-term impact of selectionism outside biological disciplines is long overdue. It is well-known that the rise of selectionism had a corrosive effect upon what is called (with an unfortunate name) "evolutionary social science" (Bannister, 2014; Bowler, 2009; Ingold, 1986; Kuklick, 1996; Lewis, 2001; Sanderson, 2007). What is insufficiently investigated, however, are the wider social values that were woven into this debate, and their repercussions for human agency, social change, and even racial differences (Livingstone, 1991). Environmentalism always came with an ambiguous moral baggage. Although obviously racism has many sources, it has not to be forgotten that environ- mentalism was one. Since the antiquity, environmental discourses were combined with value judgments and tied to proto-racist ar-guments: the fundamental linkage between people and places easily became the platform for an essentialized view of human groups as fundamentally shaped by their climate, food, or soil (Isaac, 2006; Bethencourt, 2013, pp. 13-14, 257). Arguments were employed in a very flexible way to establish a hierarchy of races based on environmental traits: either claiming that a hostile nature condemned whole human groups to inferiority; or, more subtly, that their placement in particularly unfavorable places was a sign of their subordinate nature. This moral cartography was far from disappearing in modern times. At the moment when colonial empires were made, a peculiar moral climatology emerged that strictly linked "the world's climatic regimes" to people's “moral tempera- ment” (Livingstone, 1991). If it was not climate, it could be food the medium to maintain and reinforce differences between the "body of the conquistador" and those of the colonized in the context of humoralist views of the body (Earle, 2014). Later in the eighteenth and nineteenth century, the way in which environmentalist arguments were mostly associated with the monogenist camp (Stepan, 1992, pp. 38-40) and the growing historical emphasis on hereditarianism have obfuscated the ease with which environmentalism was turned into a tool for scientific racism, arguing for the acquired inferiority of specific groups and races because of their geographic or historically acquired disadvantage. Arguments about growth and stasis, development and regression of specific civilizations were strongly tied to the direct 
environmental pressures (Montesquieu's Oriental despotism is a paradigmatic case). Claims about degeneration, especially in medical contexts, were easily combined with an environmental rhetoric that saw pathogenic places and habits as the major cause of the poisoning for whole social groups and races, something that lasted well into the early twentieth century (relevant literature in Meloni, 2016, chapters 2-3). While lots of emphasis has been put on the unpleasant moral implications of selectionism, how it was hijacked by a crude militarist rhetoric or for eugenic arguments, or the way it favored uniquely a passive view of the organism, the peculiar moral idiom of environmentalism enjoys a somehow less problematic status. This has become especially true since the mid twentieth century, when a stable association of values between environmentalism and liberal social attitudes crystallized (Pastore, 1949). However, this connection of values may be less stable than what we tend to believe (Meloni, 2016). To unearth from the weight of historical stratification the ethical complexity of the selectionism-environmentalism debate, I now focus on two texts discussing, in the aftermath of Darwin's work, the development of mental faculties. The two documents are, respectively: a) William James' short text Great Men, Great Thoughts and the Environment (from now GM); and, b) August Weismann's essay Thoughts Upon Musical Sense in Animals and Man published in 1889 in the Deutsche Rundau.

James and Weismann are two quintessentially selectionist authors. While the selectionism of Weismann, ${ }^{6}$ the proponent of the all-sufficiency of Natural Selection, does not need another expla- nation here, the case for James is subtler but just as strong (McGranahan, 2011, 2012; see also; Richards, 1987). Already at the age of twenty-three James had "reached a fairly full acceptance of Darwin's transmutation theory and rejected the most insidious argument of social Darwinism" (Richardson, 2006, p. 27). This capacity for disentangling natural selection from its most simplistic usages, makes James a unique conceptual lens

\footnotetext{
${ }^{6}$ I am not underestimating the historical critique (see Winther, 2001) that has offered a more nuanced and complex view of Weismann, quite apart from the popular ideological interpretation. This debate goes well beyond the limits of this essay. It can only be noticed in passing, however, that the article by Weismann on music I am analysing belongs to the "Phylogenetic externalism" phase (1885e1891) when Weismann hypothesized "an (almost) completely variationally-sequestered germ-plasm" (2001, p. 527), i.e. where changes in external conditions were deemed at their lowest.
} 
through which to see the wider implications of the selectionismenvironmentalism debate. Before an analysis of the two texts, a few more words on context may help. Firstly, it is important to notice that while there are no references to James in Weismann's work (to my knowledge), James in the very last pages of his Principles of Psychology was overtly appreciative of Weismann's experimental results (James, 1890, pp. 686-687). Although the analysis of Weismann occupies only few pages, James adds Weismann's contribution and his "captivating theory of descent" to his "text as it was written before 1885" (ibid., p. 686). It really looks as if James had understood his own anti-Spencerian philosophical work in perfect continuity with Weismann's critique of Lamarckism. Weismann's critique perfectly fits the anti-Spencerian mold previously elaborated by James. This is all the more interesting also considering how one of the teachers of James at Harvard was the French-American physiologist Charles Brown-Séquard whose experiments (Menand, 2001, p. 382) on the transgenerational effects of epilepsy in guinea pigs Weismann rejected (and so did James: 1890, p. 687). Besides Brown-Séquard, it is obviously Herbert Spencer's work that motivates the closest liaison between James and Weismann: Spencer's biology and psychology are the common target of James and Weismann's critiques, the "foil to set off what seems to me the truth of my own statements" as James writes in Great Mean. James' critique of Spencer dates from his very first philosophical text (James, 1878). As for Weismann, his clash with Spencer in 1893 was probably one of the most significant intellectual controversies of the last years of the century, which resonated internationally through sociology, politics, and education. I have already said how Spencer is a quintessentially environmentalist figure. There is in particular a long passage in Spencer's Principles of Psychology that I suggest can be used as the background against which both James' and Weismann's critiques may be read. This passage, cited at length in James' Psychology, is particularly significant because it perfectly combines three targets for the parallel attack of both James and Weismann. These three targets are: a) the specific environmentalist view that it is "experience's moulding finger" (James, 1890, p. 620) that shapes directly the human mind; b) the specific Lamarckian radicalization of this environmentalist trend with the notion 
that the mind owes its current shape not only to present experiences but also to past generations' experience; c) finally the subtle moral repercussions of this version of environmentalism, a crude organicism that confuses cultural acquisitions with the brain's size, and attributes human excellence not accidentally to single talented individuals but congenitally to whole populations. The human brain, Spencer writes is the:

“organized register of infinitely numerous experiences received during the evolution of life, or rather during the evolution of that series of organisms through which the human organism has been reached. The effects of the most uniform and frequent of these experiences have been successively bequeathed ( $~$ ) and have slowly mounted to that high intelligence which lies latent in the brain of the infant. Thus it happens that the European inherits from twenty to thirty cubic inches more of brain than the Papuan. Thus it happens that faculties, as of music, which scarcely exist in some inferior races, become congenital in superior ones" $(1855$, p. 583)

It is against this problematic Spencerian legacy regarding mental faculties that I suggest reading the parallel attack advanced by James and Weismann.

Great Men, Great Thoughts, and the Environment (1880).

The key argument of James' text, originally a lecture before the Harvard Natural History Society, is a "remarkable parallel ( $~$ ) between the facts of social evolution on the one hand, and of zoölogical evolution"(GM, p. 441). The theme is not extemporary in James' work. A few years later in his Principles of Psychology James clearly distinguishes between two mechanisms of evolution: a) "the "way of 'adaptation,' in which the environment may itself modify its inhabitant by exercising, hardening, and habituating him to certain sequences, and these habits may, it is often maintained, become hereditary"; b) and "the way of 'accidental variation' ( - ) in which certain young are born with peculiarities that help them and their progeny to survive" and in which causes of variations are "molecular and hidden" (1890, pp. 626e627). GM can be under- stood as an attempt to apply this latter method to what James calls elsewhere "psychogenesis", or "the factors of mental evolution" (1890, p. 627). The remarkable parallel announced at the beginning of the text is the following: just as there are two ways of conceiving 
Accepted manuscript of Meloni, M. (2017). Disentangling life: Darwin, selectionism, and the postgenomic return of the environment. Studies in History and Philosophy of Science Part C: Studies in History and Philosophy of Biological and Biomedical Sciences, 62, 10-19. Pls cite from final published version at: http://dx.doi.org/10.1016/j.shpsc.2017.02.002

organic change in zoological evolution, there are two ways to conceive the production of human genius in social evolution. One is the way of adaptation or the Spencerian "law of intelligence". Here great men are a direct "resultant" of certain "outer relations", exactly e James polemically writes e "as the pressure of water outside a certain boat will cause a stream of a certain form to ooze into a particular leak" (GM, p. 449). This is a view of the origins of intelligence that makes it thoroughly subject to the "incident forces" of external stimulation. However, there is another way to look at mental evolution, and this is Darwin's selection principle. Darwin's "trium- phant originality", James claims, was in showing "the utter insignificance in amount of ( $)$ changes produced by direct adaptation, the immensely greater mass of changes being produced by internal molecular accidents, of which we know nothing (GM, p. 444). The anti-determinist gains of this gesture are obvious: "The causes of production of great men lie in a sphere wholly inaccessible to the social philosopher. He must simply accept geniuses as data, just as Darwin accepts his spontaneous variations". Genius and its environment are radically disentangled. The first is a "stroke of evolutionary luck". The second is no longer a creator but a mere selector. "No geographical environment can produce a given type of mind. It can only foster and further certain types fortuitously produced, and thwart and frustrate others" (GM, p. 451). Against a simplistic reading of James as another nineteenth century "hero- worshipper" (in the line of a Thomas Carlyle), it is important to insist here that not only is James' analysis entirely naturalistic but also that it is far from being sociologically naïve, as Spencerians like Fiske claimed (1881). True, James' main worry in the text is Spencer and his sociological school that posits a necessary relationship between external pressures and genius (and vice versa, it excludes the emergence of genius where these outer relations are missing). Nonetheless, James is far from denying that a "social environment" is fully required to make social evolution work. "Social evolution" James writes, "is a resultant of the interaction of two wholly distinct factors, - the individual, deriving his peculiar gifts from the play of physiological and infra-social forces, but bearing all the power of initiative and origination in his hands; and, second, the social environment, with its power of adopting or rejecting both him and his gifts. Both factors are essential to change. The community stagnates without the impulse of the individual. The impulse 
dies away without the sympathy of the community" (GM, p. 448). James is here offering a view of social relationships that it is more fine- grained than the one held by the Spencerian school, Grant Allen in particular (GM, footnote 1, p. 448). His polemic is against a non- dialectical view that, as in the case of Spencer "makes the outer relations do all the work. The inner ones are plastic and without spontaneity". This lack of spontaneity is not just a psychological problem, however. If the mind is just a mechanical reflex of the outside world, (supposedly) poor human talents will invariably correspond to poor environments. Hence Spencer's racist cartog- raphy of the musical faculty: congenital in superior civilizations, and impossible in inferior ones, with the brain's size mirroring perfectly this unbalanced development. Indeed, this point emerges even more clearly from Weismann's critique.

\section{Thoughts Upon the Musical Sense in Animals and Man (1889). ${ }^{7}$}

Weismann's text has a more specific focus than James' Great Men: not genius in general but musical sense and its historical development. Beyond specific biographical sources (Weismann's predilection for music and the piano in particular, see Conklin, 1915, p. 4), the essay has to be located within a series of exchanges that in the second half of the nineteenth century addressed the evolutionary origins of music, and included Spencer (1857) and Darwin (1859). Weismann's position is rather unique in this debate. While he fully recognizes the role of natural selection in the growth of human intelligence, and of sexual selection in the development of musical sense in animals (and partly in its human origin), he disagrees that either natural or sexual selection can explain the "immense growth" in the musical sense in humans "since the earliest times" (1892, p. 37). This is exactly what makes the essay interesting. If the reproductive value of the musical talent seems nil, how can the consistent naturalist explain its "increased refinement and growth" (1892, p. 39)? There is obviously one way left, and it is Spencer's, i.e. "the inherited effects of practice" (Weismann, 1892, p. 48). Spencer had famously defended this argument since his Principles of Biology to explain the extraordinary musical advancement in the period between Bach and Beethoven. Something so spectacular, Spencer argued, "cannot rationally be ascribed to the coincidence of 'spontaneous variations" (1886, p. 250). It is exactly in countering this claim, that the richness of Weismann's 
selectionism comes to view. Not as a direct explana- tion of the growth of musical talent, but as a radical occlusion of Spencer's way. It is this occlusion that makes the search for an alternative mechanism to explain mental evolution necessary. To make this alternative mechanism visible, Weismann makes an important distinction in the essay: between music expression and musical talent. The latter has always been "inherent in man from the beginning", so the question about is supposed growth is ill- posed. The former, has in fact "undergone progressive increase and development", but this growth has nothing to do with the Spencerian increase in brain size because of the cumulative effects of practice. "Man possesses a tradition" Weismann writes; "he improves and perfects his performances by passing on the gains of each generation to those which follow" (1892, p. 49). Tradition is a very significant word in the German anthropological culture. Herder refers often to the term to convey the idea of a chain of knowledge (art, language) being handed over and refined through generations (Herder, 1772 [2002]). It is exactly in this sense that Weismann, the alleged destructor of the possibility of human progress and the value of education as neo-Lamarckian claimed, uses the term to establish a new "method of progress" alternative to the inheritance of acquired characters, and for which everyone can "seize upon the acquirements of his ancestors at the point where they left them, and ( - ) pursue them further" (1892, p. 51). It is because of this heritage, rather than a supposed hereditarian "in- crease in the capacity of the human brain", that "we can now solve more difficult problems than at the beginning of this century, or in Aristotle's day". Similarly, it is because of this heritage (which includes also technological advancements), not because of a "recent improvement in the dexterity of the human hand", that our pianists can produce better performances than in Bach's or Mozart's day.

Weismann's notion that "music is an invention and rests upon tradition" has several profound implications and two major dif- ferences with the Spencerian view. Firstly, versus Spencer's un- derstanding of the superorganic as also including animal societies, Weismann is eager to insist on the "chief difference" between an- imal development which "transforms one species into another and changes the physical nature", and the "mental" or "intellectual development of mankind [THAT] by no means necessarily entails any physical alteration even in the brain itself: it is indeed 
quite independent of any such change" (1892, p. 50 my italics). Secondly, there is the issue of musical talent among "savage nations". The Spencerian passage seems to imply a rather crude truth: given their brain size, a musical genius is not possible among savages. For Weismann things are different and much subtler: given that musical talent is the result of an undirected mutation the potential presence of musical geniuses among savages is not impossible. "From the mere fact that symphonies are not composed by sav-ages", Weismann writes "we are not entitled to conclude that Mozarts have not existed among them" (1892, p. 43). What is impossible, Weismann claims, is that this aboriginal Mozart could do more than producing a "great reform" within the existing "musical environment" of Samoa. To think differently, Weismann claims, is like to expect that Archimedes had invented "the modern dynamo as used for the transmission of energy or for electric lighting" (1892, p. 42). The difference with Spencer is obvious: the limit of the aboriginal Mozart is purely sociological for Weismann, not organically determined as in the example of the Papuans for Spencer. While the highly sociological and anthropological value of Weismannian's move has often been highlighted (Kroeber, 1917; Kroenfeldner, 2009) it seems important to emphasize here its broader implications in terms of social values. True, Weismann's text still belongs to a rather typical Eurocentric canon that thinks in terms of "stages of civilization". True, somehow inconsequently, Weismann reintroduces in the conclusion arguments about inherent human faculties (Kroeber, 1916, p. 37; Kroenfeldner, 2009). However, the racist cartography of Spencer environmentalism, with its logical connection of places and human faculties, is disrupted. It is because human potential escapes the direct determination of places that we are no longer "entitled without further proof to infer that savages never possess high musical talents because their music is but lowly developed" (1892, p. 43).

\section{Conclusion}

A new entanglement between organism and milieu is taking place in the $21 \mathrm{st}$ century. In contemporary postgenomic models, bodies do not merely "react to the environment ( - ) or withstand it", but are increasingly seen as "composed of transduced representations of environments" (Landecker, 2016b, p. 87). External 
conditions translate directly, at the molecular level, into the body's "internal biological changes" (Lappé \& Landecker, 2015); bodies "enfold molecular and social environments into their growth" (Warin et al., 2015, p. 57; see also Guthman \& Mansfield, 2013; Gowland, 2015). The formative power of the environment in instructing the organism in a directed, non-random way is increasingly at the center of novel evolutionary explorations as a crucial way to complement selectionist views (Jablonka \& Lamb, 2014; Rosenberg, Sharon, ZilberRosenberg, 2009a), including claims of a return to soft or plastic heredity (Richards, 2006; Bonduriansky, 2012; Lamm and Jablonka, 2008). Notions like inscription, embodiment, embedment, nature-culture, and entan- glement are part of this emerging conceptual repertoire. The environment that was once utterly separated is now once again flooding over the newly porous organism. Some of the implications of this shift in terms of knowledge production are rapidly coming to light: ideas of culture (or tradition) as purely extraorganic are challenged by a novel mixture of biosocial and biocultural approaches in social and anthropological research (Ingold \& Palsson, 2013; Frost, 2016; Meloni, Williams, \& Martin, 2016). An epigenetics of culture, for instance, although "still in its infancy", aims to show how "cultural practices" can lead to "molecular epigenetic changes that in turn can contribute to the reconstruction of the system's dynamics" (Jablonka, 2016, p. 46). What remains a radical terra incognita in this scenario are the moral and political implications of this new entanglement, between bodies and milieu but also across generations. What does it mean for notions of human agency, social change and racial differences that the immediate and recent environment matters more than we previously thought? What shall we expect from claims that past and present social experiences leave a relatively stable imprint on the biology of certain groups and explain racial differences in health (Jasienska, 2009; Kuzawa \& Sweet, 2009)? What about the almost perfect correspondence between disadvantaged places and abnormal epigenetic expression, for whole groups not just individuals, claimed today in fields like epidemiological epigenetics (McGuinness et al., 2012)? And what are the moralistic implications of the growing evolutionary emphasis on parental effects, espe- cially when they involve mothers (Richardson, 2015)?

Rather than answering these questions directly and in a pre- scriptive fashion, I 
have preferred in this essay to take a longer genealogical perspective and show the complexity of the moral discourse associated with the selectionistenvironmentalist debate, with its often counterintuitive and paradoxical implications. A whole new landscape of ethical quandaries is rapidly unfolding in postgenomics. No assurance is given that a decline in selectionist thinking will correspond to more pleasant social attitudes.

\section{Acknowledgments}

I thank Andrew Turner for his help with language and Jan Baedke (Bochum) for important conceptual suggestions and bibliographic references. The three anonymous reviewers sent really though-provoking comments to my first iteration. I gratefully acknowledge funding from the Leverhulme Trust for a grant on epigenetics and inequality in health at the Dept of Sociological Studies University of Sheffield (PI Paul Martin).

\section{References}

Alder, K. (2013). The history of science as oxymoron: From scientific exceptionalism to episcience. Isis, 104(1), 88e101.

Amundson, R. (1994). John t. Gulick and the active Organism: Adaptation, isolation, and the politics of evolution. In P. Rehbock, \& R. MacLeod (Eds.), Vol 1994. Darwin in the pacific (pp. 110e139). University of Hawaii Press.

Amundson, R. (1996). Historical development of the concept of adaptation. In M. R. Rose, \& G. V. Lauder (Eds.), Adaptation (pp. 11e53). New York: Academic Press.

Bannister, R (1988). Social Darwinism: Science and myth in anglo-american thought (2nd ed.). Philadelphia, PA: Temple University Press.

Bannister, R. (2014). Sociology and Scientism: The American Quest for Objectivity, 1880-1940. The University of North Carolina Press.

Bethencourt, F. (2013). Racism: From the crusades to the twentieth century.

Princeton: Princeton University Press

Bertillon, J. (1872). De l'influence des milieux ou mésologie. Bulletins de la Société d'anthropologie de Paris, 7(1), 711e728.

Bidney, D. (1953). Theoretical anthropology. New York: Columbia University PressF. 
Bodin, J. (1576/1962). In K. D. MacRae (Ed.), The Six books of a Commonwealth. Cambridge M. A.: Harvard University Press.

Bonduriansky, R. (2012). Rethinking heredity, again. Trends in Ecology \& Evolution, $27(6), 330 \mathrm{e} 336$.

Bowler, P. (2009). Evolution, the history of an idea (3rd ed.). Berkeley: University of California Press.

Braunstein, J.-F. (1997). Le concept de milieu, de Lamarck à Comte et aux positivismes. In G. Laurent (Ed.), Jean-baptiste Lamarck, 1744e1829 (pp. 557e571). Paris: CTHS.

Browne, J. (2002). Charles Darwin: A biography, vol. 2, the power of place. Princeton NJ: Princeton University Press.

Burkhardt, R.W. (1977). The spirit of system: Lamarck and evolutionary biology. Cambridge, MA: Harvard University Press.

Campbell, J. A., \& Livingstone, D. (1983). Neo-lamarckism and the development of geography in the United States and Great Britain. Transactions of the Institute of British Geographers, 8(3), 267e294.

Canguilhem, G. (2001). The living and its milieu. Grey room 3 (spring). Conklin, E. G. (1915). August Weismann. Science, 1069(41), 917e923.

Corsi, P. (1988). The Age of Lamarck. Berkeley (CA): University of California Press.

Darwin, C. (1845 [1937]). Voyage of the beagle. New York: Collier and Son.

Darwin, C. (1859 [1985]). The origin of species by means of natural selection. Edited with an introduction by J.W. Burrow. Penguin Books.

Desmond, A. (1990). The politics of evolution. Morphology, medicine and reform in Radical London. Chicago: University of Chicago Press.

Earle, R. (2014). The body of the Conquistador: Food, race and the colonial experience in spanish America, 1492-1700. Cambridge: Cambridge UP.

Febvre, L. (1924). A geographical introduction to history. London: Routledge, Trench and Tubner.

Fiske, J. (1881). Sociology and hero-worship. Atlantic Monthly, 47(January), 75e84.

Frost, S. (2016). Biocultural Creatures: Toward a new theory of the human. Durham, NC: Duke University Press.

Gillispie, C. (1959). Lamarck and Darwin in the history of science. In B. Glass, O. Temkin, \& W. Straus, Jr. (Eds.), Forerunners of Darwin: 1745e1859 (pp. 265e 291). Baltimore: Johns Hopkins University Press.

Gissis, S. (2011). Lamarckian problematics in historical perspective in. In S. Gissis, \& E. Jablonka (Eds.), Transformations of lamarckism:from subtle fluids to molecular biology (pp. 21e32). Cambridge, Mass: MIT Press.

Glacken, C. (1967). Traces on the rhodian Shore: Nature and culture in western thought from ancient times to the end of the eighteenth century. Berkeley: University of 


\section{California Press.}

Gould, S. J. (2002). The structure of evolutionary theory. Cambridge (Mass): Harvard University Press.

Gowland, R. (2015). Entangled lives: Implications of the developmental origins of health and disease hypothesis for bioarchaeology and the life course. American journal of physical anthropology, 158(4), 530e540.

Guthman, J., \& Mansfield, B. (2013). The implications of environmental epigenetics: A new direction for geographic inquiry on health, space, and nature-society relations. Progress in Human Geography, 37(4), 486e504.

Herder, J. G. (1772 [2002]). In M. N. Forster (Ed.), Treatise on the origin of language" in herder. philosophical writings (pp. 65e163). Cambridge: Cambridge University Press.

Hodge, J. (2009). Darwin, the galapagos and his changing thoughts about species origins: 1835-1837. Proceedings of the California Academy of Sciences Ser. 4, 61(Supplement II), 89e106. No. 7.

Ingold, T. (1986). Evolution and social life. Cambridge: Cambridge University Press.

Ingold, T., \& Palsson, G. (2013). Biosocial Becomings: Integrating social and biological anthropology. Cambridge: Cambridge University Press.

Isaac, B. (2006). The invention of racism in classical antiquity. Princeton: Princeton University Press.

Jablonka, E. (2016). Cultural epigenetics. The Sociological Review Monographs, 64, $42 \mathrm{e} 60$.

Jablonka, E., \& Lamb, M. (2014). Evolution in four dimensions (2nd ed.). Cambridge, Mass: MIT Press.

James, W. (1878). Remarks on Spencer's definition of mind as correspondence. Journal of Speculative Philosophy, 12(January), 1e18.

James, W. (1880). Great men, great thoughts, and the environment. Atlantic Monthly, 46, $441 \mathrm{e} 459$.

James, W. (1890). The principles of psychology (Vol. 1 and Vol. 2)New York: Holt and Co.

James, W. (1988). Manuscript lectures. Cambridge: Harvard University Press. Jasienska, G. (2009). Low Birth Weight of Contemporary African Americans: An Intergenerational Effect of Slavery? American Journal of Human Biology, 21, 16e

Johnson, C. (2015). Darwin's Dice: The Idea of Chance in the Thought of Charles Darwin. Oxford: Oxford University Press.

Jordanova, L. (1984). Lamarck. Oxford: Oxford University Press.

Jordanova, L. (1989). Nature's powers: A reading of Lamarck's distinction between creation and production. In J. R. Moore (Ed.), History, humanity, and evolution. Cambridge: Cambridge University Press. 
Koller, A. (1918). An outline of the history of the idea of milieu, and its present status. Menasha (Wis): Banta publishing company

Koonin, E., \& Wolf, Y. (2009). Is evolution darwinian or/and lamarckian? Biology Direct, 4, 42e57.

Kroeber, A. (1916). The cause of the belief in use inheritance. The American Naturalist, 50, 367e370.

Kroeber, A. (1917). The superorganic. American Anthropologist, 19, 163e213.

Kroenfeldner, M. (2007). Is cultural evolution lamarckian? Biology \& Philosophy, $22(4), 493$ e 512.

Kroenfeldner, M. (2009). 'If there is nothing beyond the organic - ': Heredity and culture at the boundaries of anthropology in the work of Alfred L. Kroeber', NTM. Journal of the History of Science, Technology and Medicine, 17, 107e133.

Kuklick, H. (1996). Islands in the Pacific: Darwinian biogeography and British anthropology. American Ethnologist, 23, $611 \mathrm{e} 638$.

Kuzawa, C. W., \& Sweet, E. (2009). Epigenetics and the embodiment of race: Developmental origins of US racial disparities in cardiovascular health. Amer-ican Journal of Human Biology, 21, 2e15.

Lamm, E., \& Jablonka, E. (2008). The nurture of Nature: Hereditary plasticity in evolution. Philosophical Psychology, 21(3), 305e319.

Landecker, H. (2016a). It is what it eats: Chemically defined media and the history of surrounds. Studies in History and Philosophy of Biological and Biomedical Sciences, 57, 148e 160 .

Landecker, H. (2016b). The social as signal in the body of chromatin. In M. Meloni, S. Williams, \& P. Martin (Eds.), Biosocial Matters: Rethinking sociology-biology relations in the twenty-first century. Oxford: Wiley Blackwell.

Landecker, H., \& Panofsky, A. (2013). From social structure to gene regulation, and back: A critical introduction to environmental epigenetics for sociology. Annual Review of Sociology, 39, $18 \mathrm{e} 25$.

Lappé, M., \& Landecker, H. (2015). How the genome got a life span. New Genetics and Society, 34(2), 152e176.

Lennox, J. (2015). Darwinism. In E. N. Zalta (Ed.), The stanford encyclopedia of philosophy. http://plato.stanford.edu/archives/sum2015/entries/darwinism/.

Lewis, H. S. (2001). Boas, Darwin, science, and anthropology. Current Anthropology, $42(3), 381 \mathrm{e} 406$.

Lewontin, R. C. (1983). The organism as the subject and object of evolution, repr. In R. Levins, \& R. C. Lewontin (Eds.), 1985, the dialectical biologist (pp. 85e106). Cambridge, MA: Harvard University Press.

Livingstone, D. (1991). The moral discourse of Climate: Historical considerations on race, place, and virtue. J. Hist. Geogr, 17, 413e434. 
Livingstone, D. (1992). The geographical Tradition: Episodes in the history of a con-tested enterprise. Oxford: Blackwell.

Lloyd, G. E. R. (1978). Hippocratic Writings. Harmondsworth England: Penguin Books.

Loison, L. (2010). Qu'est-ce que le néolamarckisme? Les biologistes français et la question de l'évolution des espèces, 1870-1940. Paris: Vuibert.

Martin, A. Warin, M. (in press). Emergent epigenetic bodies and their (non)scalable environments, In Meloni, M. Cromby, J. Fitzgerald, D. Lloyd, S. (Eds.), Handbook of biology and society. Basingstoke (UK) Palgrave

Mayr, E. (1972). Lamarck revisited, repr. In E. Mayr (Ed.), 1976, evolution and the diversity of Life: Selected essays (pp. 222e250). Cambridge, MA: Harvard University Press.

McGranahan, L. (2011). William James's social evolutionism in focus. The Pluralist, $6,80 \mathrm{e} 92$.

McGranahan, L. (2012). William James's evolutionary pragmatism: A study in physiology, psychology, and philosophy at the close of the nineteenth century. Diss. University of California Santa Cruz.

McGuinness, D., et al. (2012). Socio-economic status is associated with epigenetic differences in the pSoBid cohort. International Journal of Epidemiology, 41(1), 151-160.

Meloni, M. (2016). Political Biology: Science and social values in human heredity from eugenics to epigenetics. London: Palgrave.

Meloni, M., Williams, S., \& Martin, P. (2016). Biosocial Matters: Rethinking the sociology-biology relations in the twenty-first century. Oxford: Wiley Blackwell.

Menand, L. (2001). The metaphysical club: A story of ideas in America. New York: Farrar, Straus and Giroux.

Meyer, J. M. (1999). Interpreting nature and politics in the history of Western thought: The environmentalist challenge. Environmental Politics, 8(2), 1-23.

Moczek, A. P. (2015). Re-evaluating the environment in developmental evolution. Frontiers in Ecology and Evolution, 3(7), 1-8.

Montesquieu, C. S. (1752/1914). The spirit of laws. Translated by Thomas Nugent, revised by J. V. Prichard. London: Bell \& Sons.

Nash, L. (2006). Inescapable ecologies: A history of environment, disease, and knowledge. University of California Press.

Newton, T. (2007). Nature and sociology. London: Routledge.

Olby, R. (2009). In M. Ruse, \& R. Richards (Eds, ), The cambridge companion to the origin of species'. Cambridge: Cambridge University Press.

Ospovat, D. (1995). The development of Darwin's Theory: Natural history, natural theology, and natural selection, 1838-1859. Cambridge: Cambridge University Press.

Pastore, N. (1949). The nature-nurture controversy. New York: King’s Crown Press. 
Paul, D. (2009). Darwin, social darwinism, and eugenics. In J. Hodge, \& G. Radick (Eds.), The cambridge companion to Darwin (2nd ed.). (pp. 219e245) Cambridge: Cambridge University Press.

Pearce, T. (2010). From 'circumstances' to 'Environment': Herbert spencer and the origins of the idea of organism-environment interaction. Studies in History and

Philosophy of Biological and Biomedical Sciences, 41, 241e252

Petit, A. (1997). L'héritage de Lamarck dans la philosophie positive d'Auguste Comte. In G. Laurent (Ed.), Jean- baptiste Lamarck, 1744e1829 (pp. 543e556). Paris: CTHS.

Ribot, T. (1874). English psychology. New York: Appleton.

Richards, R. (1987). Darwin and the emergence of evolutionary theories of mind and behavior. Chicago: University of Chicago Press.

Richards, E. (2006). Inherited epigenetic variation: Revisiting soft inheritance. Na-ture Reviews Genetics, 7, 395e401.

Richardson, R. (2006). William James: In the maelstrom of american modernism. Boston: Houghton Mifflin.

Richardson, S. (2015). Maternal bodies in the postgenomic order: Gender and the explanatory landscape of epigenetics. In S. Richardson, \& H. Stevens (Eds.), Postgenomics: Perspectives on biology after the genome (pp. 210e231). Durham, NC: Duke University Press.

Rosenberg, C. E. (2012). Epilogue: Airs, waters, places. A status report. Bulletin of the History of Medicine, 86(4), 661e670.

Rosenberg, E., Sharon, G., \& Zilber-Rosenberg, I. (2009a). The hologenome theory of evolution contains Lamarckian aspects within a Darwinian framework. Envi-ronmental Microbiology, 11, 2959e2962.

Sanderson, S. (2007). Evolutionism and its Critics: Deconstructing and reconstructing an evolutionary interpretation of human society. Boulder (CO): Paradigm Pub- lisher Press.

Shostak, S., \& Moinester, M. (2015). The missing piece of the Puzzle? Measuring the environment in the postgenomic moment. In S. Richardson, \& H. Stevens (Eds.), Postgenomics: Perspectives on biology after the genome (pp. 192e209). London: Duke University Press.

Sloan, P. R. (1973). The idea of racial degeneracy in Buffon's histoire naturelle in pagliaro. In Racism in the eighteenth century (Vol. 3, pp. 293e321). Cleveland: Case Western Reserve University.

Spencer, H. (1855). The principles of psychology. London: Longman, Brown, Green, and Longmans. 
Spencer, H. (1857). Progress: Its law and causes. Westminster Review, 67(April), $445 \mathrm{e} 447$.

Spencer, H. (1877). The principles of sociology (Vol. 1). London: Williams and Norgate.

Spencer, H. (1886). The principles of biology (Vol. 1). New York: Appleton and Co.

Stepan, N. (1992). The idea of race in Science: Great britain. 1800-1960. London: Macmillan.

Spitzer, L. (Dec 1942). Society Milieu and Ambiance: An Essay in Historical Semantics. Philosophy and Phenomenological Research, 3(No. 2), 169-218.

Thomas, F. (1925). The environmental basis of society. New York and London: The Century Company.

Tooley, M. (1953). Bodin and the mediaeval theory of climate. Speculum, 28(1), 64e 83.

Tresch, J. (2012). The romantic Machine: Utopian science and technology after Napoleon. Chicago: Univ. Chicago Press.

Warin, M., Moore, V., Davies, M., \& Ulijaszek, S. (2015). Epigenetics and Obesity he Reproduction of Habitus through Intracellular and Social Environments. Body \& Society, 22(4), 53e 78.

Weinstein, D. (1998). Equal freedom and Utility: Herbert Spencer's liberal utilitarianism. Cambridge: Cambridge University Press.

Weismann, A. (1892). Thoughts upon the musical sense in animals and man. In E. B. Poulton, \& A. E. Shipley (Eds.), Essays upon heredity and kindred biological problems. Oxford: Clarendon Press.

Winther, R. (2000). Darwin on variation and heredity. Journal of the History of Biology, 33(3), 425e455.

Winther, R. (2001). August Weismann on germ-plasm variation. Journal of the History of Biology, 34, 517e555.

Worster, D. (1985). Nature's economy: A history of ecological ideas. Cambridge: Cambridge University Press.

Zirkle, C. (1946). The early history of the idea of the inheritance of acquired characters and of pangenesis. Transactions of the American Philosophical Society, 35, $91 \mathrm{e} 151$. 
Accepted manuscript of Meloni, M. (2017). Disentangling life: Darwin, selectionism, and the postgenomic return of the environment. Studies in History and Philosophy of Science Part C: Studies in History and Philosophy of Biological and Biomedical Sciences, 62, 10-19. Pls cite from final published version at: http://dx.doi.org/10.1016/j.shpsc.2017.02.002 